\title{
Driver Behavior Influenced by an Aggressive Factor
}

\author{
J. Faber, Z. Lisá* \& M. Novák* \\ Faculty of Transportation Sciences, Czech Technical University of Prague, 11000 Prague 1, Czech Republic \\ *Corresponding authors: zuzana.lisa@mdcr.cz,novak@fd.cvut.cz
}

\begin{abstract}
This paper presents systematic research dealing with aggressive driving in the Czech Republic. There is limited information concerning reckless driving, aggressive driving or road rage either in the Czech Republic or in European Union. A lot of opinion polls were carried out, unfortunately based on subjective feelings, which refer to some differences (e.g. gender or age). The systematic survey of driver's behavior, which proceeds further in cooperation with Faculty of Transportation Science, Ministry of Transport and Police Headquarters, is helping to describe the aggressive behavior of drivers in the Czech Republic and suggest possible ways to avoid this risk factor.
\end{abstract}

KEY WORDS: reckless driving, aggressive driving, road rage, road accident, prevent.

\section{INTRODUCTION}

The majority of road accidents are still caused by human factor, either by vehicle drivers or the other road users. According to the world statistics it seems to be between $50-70 \%$ of all road accidents. According to the impact assessment study completed in 2007, the most serious offences of accidents caused by human factor in the EU are:

1. Speeding (30\% road fatalities)

2. Influence of alcohol ( $25 \%$ road fatalities)

3. Non-use of seat belts (17\% road fatalities)

4. Failing to stop at a red light ( $4 \%$ road fatalities)

In other words, some $75 \%$ of all road deaths are caused by one (or more) of these four traffic offences. Aggressive driving might be involved in all of these offences (with the exception of not using seat belts); therefore it can be considered seriously dangerous and worthy of investigation. For this reason systematic research on the field of aggressive behavior started about two years ago. The goal of the research was to analyze the current situation on the Czech roads, concerning events which could be classified as aggressive behavior, including their classification into several categories.

For the systematic surveying of drivers' aggressive behavior in the Czech territory, a special research team was created: the Faculty of Transportation Sciences in cooperation with the Ministry of Transport and the Police Headquarters. 


\section{CONCEPT DEFFINITIONS}

Aggressive driving is not properly defined in Czech terminology. It would therefore be useful to have a look into American terminology, where aggressive driving is described in each form. There are three main conceptions concerning aggressive driving (source: NHTSA - National Highway Traffic Safety Administration; Washington, USA):

1. Reckless driving - driving with no/less respect for the other road users.

2. Aggressive driving - "when individuals commit a combination of moving traffic offences so as to endanger other persons or property". Some other institutions prefer another definition: "the operation of a motor vehicle involving three or more moving violations as part of a single continuous sequence of driving acts, which is likely to endanger any person or property." Some behaviors typically associated with aggressive driving include: exceeding the posted speed limit, following too closely, erratic or unsafe lane changes, failure to obey traffic control devices (stop signs, yield signs, traffic signals, railroad grade cross signals, etc.).

3. Road rage - is a criminal offence, "an assault with a motor vehicle or other dangerous weapon by the operator or passenger(s) of one motor vehicle on the operator or passenger(s) of another motor vehicle or is caused by an intent that occurred on a roadway.”The mentioned above investigation considers Reckless and Aggressive driving.

\section{AVAILABLE INFORMATION ABOUT AGGRESSIVE DRIVING}

Czech Republic is one of the few states in European Union that has a "Reckless/Aggressive driving" category included in road accident statistics. The percentage in this category of the total number of road accidents in the Czech Republic is about $0.5 \%$. Although this data is based only on witness's statements, table 1 adverts to gender differences. It is worth noting that the general number of accidents is decreasing in contrast to the rate for women which is increasing. Further data investigation also shows age differences.

Table 1: Reckless/Aggressive driving, item 12-506 (source: Police Headquarters)

\begin{tabular}{|c|c|c|c|}
\hline year & $\begin{array}{c}\text { number of } \\
\text { accidents }\end{array}$ & $\begin{array}{c}\text { offender } \\
\text { men/women }\end{array}$ & $\begin{array}{c}\text { killed } \\
\text { persons }\end{array}$ \\
\hline 2005 & 570 & $511 / 59$ & 7 \\
\hline 2006 & 590 & $518 / 72$ & 5 \\
\hline 2007 & 554 & $472 / 82$ & 2 \\
\hline 2008 & 550 & $468 / 82$ & 2 \\
\hline
\end{tabular}

Several opinion polls which were undertaken all around the world can also help as another source of information focusing on aggressive driving. These opinion polls are also based on the subjective feelings of polled persons, but take into account gender and age differences (e.g. men hate to feel limited by other drivers, women hate to be endangered, aggressive ways of driving seems to be rising, etc.). There are several causes, which can launch aggressive behavior on the roads. It might be competitive instinct, inferiority complex, an occasion 
to punish the other road users, or social standards (common or normal behavior). These causes can also be intensified by high testosterone level or premenstrual syndrome which is also caused by higher testosterone and lower estrogen level. The following hypothesis about victims is based on the above-mentioned facts: they are probably young drivers (20-35 years), due to a low level of responsibility and foresight, higher temperament and risky behavior, and probably of male gender, because of the higher testosterone levels and competitive instinct, etc.

\section{INVESTIGATION PROCEDURE - THE FIRST STEP}

The first step of aggressive behavior investigation undertakes to analyze a real situation on the Czech roads. There are three floating cars equipped with digital cameras installed on the top of cockpit front panel currently used for this experiment. This camera records the main part of the front field of view as seen by the car driver.

Systematic filling of the database with records of the driver's behavior in real-life situations on roads started in spring 2007. Fully digital cameras are used for recording (Panasonic SDR-S 150E and Sony HDR-CX6). For short distances (up to about 5m), the recorded quality allows one to recognize the number plate of the car in front. A recorded example is shown in figure 1Figure 1.

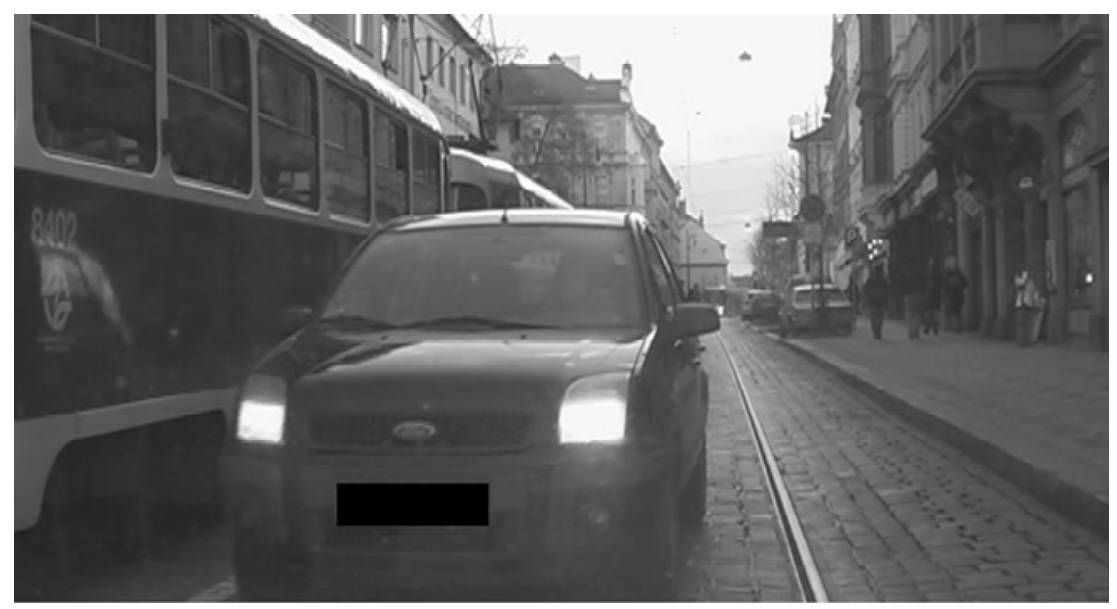

Figure 1: Recorded quality - car overtaking a tram in Prague city center, neglecting also the solid white line and red light (Panasonic SDR-S 150E camera)

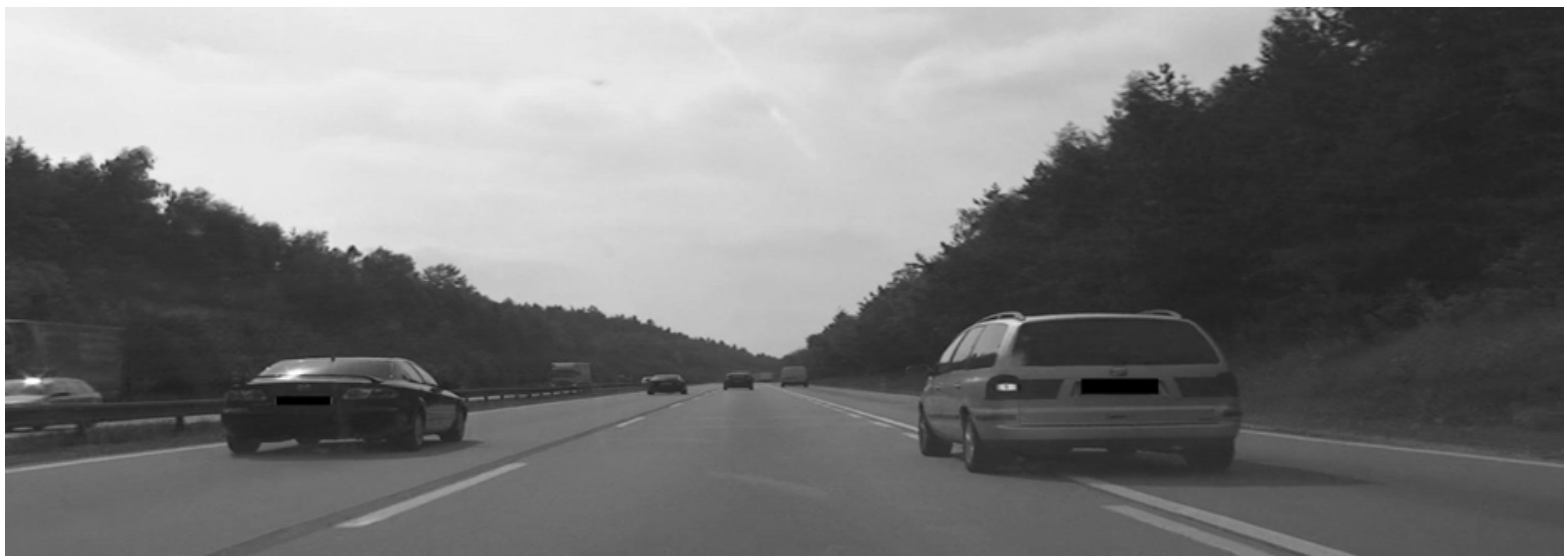

Figure 2: Recorded quality - overtaking from the right side across the solid line on motorway (Sony HDR-CX6 camera) 
Floating cars are driven mainly through Central Bohemia Region, Prague, motorway D1, etc. Each record is properly described in the database, including the important data about the offence, location, type and color of the vehicle, driving time period and in some cases also victim description, see table 3 (license numbers are willfully intercepted). There are about 177 records of various lengths currently described in the database, which is continuously filled in. The average recording length is about 20 minutes, total length is 61 hours. There are about 577 items with aggressive behavior described in the table. When we compare it to the number of total driving license holders in the Czech Republic, which are $6398585^{1}$ (including passive drivers), we will find 577 cases to be an interesting sample size $(0,01 \%)$. Distribution of the driving directions according to road type was almost equally divided - 53 \% rural area, $47 \%$ urban area (shown in table 2).

Table 2: Road type

\begin{tabular}{|c|c|c|c|}
\hline road type & urban area & rural area & motorway \\
\hline driving time [\%] & 47 & 33 & 20 \\
\hline
\end{tabular}

Table 3: Database structure - example

\begin{tabular}{|c|c|c|c|c|c|c|c|c|c|c|c|c|}
\hline & & & \multicolumn{3}{|c|}{ Offence description } & \multirow[b]{2}{*}{ route } & \multirow[b]{2}{*}{$\begin{array}{l}\text { loca- } \\
\text { lity }\end{array}$} & \multicolumn{2}{|c|}{ Time of event } & \multicolumn{3}{|c|}{ Vehicle } \\
\hline $\begin{array}{l}\text { vid. } \\
\text { No. }\end{array}$ & date & $\begin{array}{l}\text { start } \\
\text { time }\end{array}$ & speeding & $\begin{array}{l}\text { over- } \\
\text { taking }\end{array}$ & $\begin{array}{c}\text { ot } \\
\text { h } \\
\text { er } \\
\text { s }\end{array}$ & & & $\begin{array}{l}\text { actual } \\
\text { mm:ss }\end{array}$ & $\begin{array}{l}\text { total } \\
\text { mm:ss }\end{array}$ & color & type & $\begin{array}{l}\text { lic. } \\
\text { No. }\end{array}$ \\
\hline \multirow{8}{*}{ N4 } & $\begin{array}{l}19.9 . \\
2007\end{array}$ & 10:09 & $\begin{array}{c}\text { cca } 20 \\
\mathrm{~km} / \mathrm{h} \text { over }\end{array}$ & & & $\begin{array}{c}\text { D5 } \\
\text { Prague } \\
\text { Plilsen }\end{array}$ & & $9: 42$ & $50: 37$ & & bus & \\
\hline & & & & $\begin{array}{c}\text { in- } \\
\text { consider } \\
\text { over-taking }\end{array}$ & & & $\begin{array}{c}\text { Motor } \\
\text { way }\end{array}$ & $14: 37$ & & & Avia & $\begin{array}{l}2 \mathrm{~K} 1 \\
\mathrm{xxxx}\end{array}$ \\
\hline & & & $\begin{array}{c}\text { over- } \\
\text { speeding }\end{array}$ & $\begin{array}{l}\text { breaking } \\
\text { safe } \\
\text { distance }\end{array}$ & & & $\begin{array}{c}\text { Motor } \\
\text { way }\end{array}$ & $15: 30$ & & black & $\begin{array}{c}\text { Škoda } \\
\text { Octavia II } \\
\text { combi }\end{array}$ & $\begin{array}{r}6 \mathrm{~A} 2 \\
\mathrm{xxxx}\end{array}$ \\
\hline & & & $\begin{array}{c}\text { over- } \\
\text { speeding }\end{array}$ & $\begin{array}{l}\text { breaking } \\
\text { safe } \\
\text { distance }\end{array}$ & & & $\begin{array}{c}\text { Motor } \\
\text { way }\end{array}$ & $\begin{array}{c}18: 49 \\
\text { and } \\
44: 49 \\
\text { again } \\
\end{array}$ & & $\begin{array}{l}\text { Silve } \\
\mathrm{r}\end{array}$ & BMW 5 & $\begin{array}{r}1 \mathrm{H} 4 \\
\mathrm{xxxx}\end{array}$ \\
\hline & & & $\begin{array}{c}\text { over- } \\
\text { speeding }\end{array}$ & $\begin{array}{l}\text { breaking } \\
\text { safe } \\
\text { distance }\end{array}$ & & & $\begin{array}{c}\text { Motor } \\
\text { way }\end{array}$ & $22: 45$ & & white & $\begin{array}{l}\text { Škoda } \\
\text { Fabia } \\
\text { combi }\end{array}$ & $\begin{array}{l}4 \mathrm{~A} 1 \\
\mathrm{xxxx}\end{array}$ \\
\hline & & & $\begin{array}{c}\text { over- } \\
\text { speeding }\end{array}$ & $\begin{array}{l}\text { breaking } \\
\text { safe } \\
\text { distance }\end{array}$ & & & $\begin{array}{c}\text { Motor } \\
\text { way }\end{array}$ & $22: 52$ & & $\begin{array}{c}\text { metal } \\
\text { l. } \\
\text { gray }\end{array}$ & $\begin{array}{c}\text { Audi A6 } \\
\text { (slightly } \\
\text { damaged } \\
\text { from rear) }\end{array}$ & $\begin{array}{r}5 \mathrm{~A} 6 \\
\mathrm{xxxx}\end{array}$ \\
\hline & & & $\begin{array}{c}\text { over- } \\
\text { speeding }\end{array}$ & $\begin{array}{l}\text { breaking } \\
\text { safe } \\
\text { distance }\end{array}$ & & & $\begin{array}{c}\text { Motor } \\
\text { way }\end{array}$ & $32: 00$ & & white & $\begin{array}{c}\text { Škoda } \\
\text { Fabia } \\
\text { combi }\end{array}$ & $\begin{array}{r}5 \mathrm{~A} 5 \\
\mathrm{xxxx}\end{array}$ \\
\hline & & & $\begin{array}{c}\text { cca } 20 \mathrm{~km} / \mathrm{h} \\
\text { over }\end{array}$ & & & & $\begin{array}{c}\text { Motor } \\
\text { way }\end{array}$ & $32: 37$ & & $\begin{array}{c}\text { metal } \\
\text { l. } \\
\text { gray }\end{array}$ & $\begin{array}{c}\text { VW } \\
\text { Passat }\end{array}$ & $\begin{array}{l}3 \mathrm{~A} 0 \\
\mathrm{xxxx}\end{array}$ \\
\hline
\end{tabular}

Observed aggressive events are possible to divide into several parts, shown in Tabletable 4. When the driver commits more than one offence at the same time, only the most serious

\footnotetext{
${ }^{1}$ Up to 31. 12. 2008. $60 \%$ men, $40 \%$ women.
} 
offence is included in the table. (e.g. if speeding is combined with aggressive overtaking, only overtaking is included) ${ }^{2}$.

Table 4: The example of results

\begin{tabular}{|c|c|c|c|c|c|c|c|}
\hline offence & $\begin{array}{l}\text { freq. } \\
\text { urban } \\
\text { area }\end{array}$ & $\begin{array}{c}\text { urban } \\
\text { area } 4 \\
\text { traffic } \\
\text { lanes } \\
\end{array}$ & $\begin{array}{l}\text { freq. } \\
\text { rural } \\
\text { area }\end{array}$ & $\begin{array}{l}\text { motor- } \\
\text { way }\end{array}$ & $\begin{array}{c}\text { freq. } \\
\text { total } \\
\text { (urban } \\
+ \text { rural) } \\
\end{array}$ & $\begin{array}{l}\text { freq. tota } \\
\text { (\% share } \\
\text { from total }\end{array}$ & $\begin{array}{l}\text { type of the } \\
\text { vehicle }\end{array}$ \\
\hline $\begin{array}{l}\text { over speeding up to } 15 \\
\text { km/h }\end{array}$ & & & \multicolumn{5}{|c|}{ insignificant } \\
\hline $\begin{array}{l}\text { over speeding, c. } 15 \\
\text { km/h }\end{array}$ & 40 & 34 & 60 & 50 & 100 & 17,3 & $\begin{array}{c}\text { 79xOA, 9xOR, 8xD, } \\
4 x M\end{array}$ \\
\hline $\begin{array}{l}\text { over speeding, c. } 20 \\
\text { km/h }\end{array}$ & 13 & 12 & 67 & 61 & 80 & 13,9 & $\begin{array}{l}\text { 61xOA, 11xM, } \\
4 \mathrm{xOR}, 2 \mathrm{xD}, 2 \mathrm{xA}\end{array}$ \\
\hline $\begin{array}{l}\text { over speeding more } \\
\text { than } 20 \mathrm{~km} / \mathrm{h}\end{array}$ & 3 & 2 & 43 & 32 & 46 & 8 & $\begin{array}{c}\text { 34xOA, 6xM, } \\
4 x O R, 2 x D\end{array}$ \\
\hline $\begin{array}{l}\text { aggressive overtaking/ } \\
\text { tram overtaking/ } \\
\text { improper lane } \\
\text { changing/ braking } \\
\text { continuous line) }\end{array}$ & 90 & 42 & 29 & 14 & 119 & 20,6 & $\begin{array}{c}\text { 75xOA, 22xM, } \\
\text { 10xD, 6xN, 5xOR, } \\
\text { 1xA }\end{array}$ \\
\hline $\begin{array}{l}\text { overtaking from the } \\
\text { right side (traffic in } \\
\text { lines excl.) }\end{array}$ & & & 37 & 37 & 37 & 6,4 & $\begin{array}{l}22 x O A, 13 x M \\
1 x O R, 1 x D\end{array}$ \\
\hline breaking safe distance & 36 & 31 & 93 & 91 & 129 & 22,4 & $\begin{array}{c}\text { 119xOA, 7xOR, } \\
\text { 3xD }\end{array}$ \\
\hline $\begin{array}{l}\text { pedestrians (crossing } \\
\text { on red signal/besides } \\
\text { ped. crossing), reckless } \\
\text { cyclists }\end{array}$ & 24 & 4 & 1 & & 25 & 4,3 & $22 x P, 3 x C$ \\
\hline too slow driving & 7 & 0 & 8 & 8 & 15 & 2,6 & 12xOA, 2xN, 1xA \\
\hline other & 3 & 1 & 5 & 3 & 8 & 1,4 & $\begin{array}{l}\text { 5xOA, } 1 \mathrm{xN}, 1 \mathrm{xM} \\
1 \mathrm{xD}\end{array}$ \\
\hline failing to give way & 5 & 2 & 2 & 2 & 7 & 1,2 & $\begin{array}{c}4 \mathrm{xOA}, 1 \mathrm{xD}, 1 \mathrm{xM}, \\
1 \mathrm{xN}\end{array}$ \\
\hline $\begin{array}{l}\text { incorrect road signs or } \\
\text { signals }\end{array}$ & 1 & 0 & 5 & 2 & 6 & 1 & \\
\hline $\begin{array}{l}\text { turning across the } \\
\text { continuous line }\end{array}$ & 5 & 1 & 0 & 0 & 5 & 0,9 & $3 x O A, 2 x N$ \\
\hline
\end{tabular}

\section{Explanatory notes:}
O - Off Road/SUV
$\mathrm{M}$ - Motorcycle
$\mathrm{N}$ - Truck
$\mathrm{C}-$ Cyclist(s)

D - Van/Pick-up

A - Bus

OA - Passenger car

$\mathrm{P}$ - Pedestrian(s)

The percentage distribution of offences from table 4 is shown in figure 3 . There are about 577 offences, from 177 records in Table4, described during the almost one year terrain investigation procedure (from autumn 2007 till summer 2008). The total length

\footnotetext{
${ }^{2}$ Number of combinated items: 129 (22,4 \%), mainly overspeeding with breaking safe distance.
} 
of described records is 61 hours (exactly 3667 minutes). The most frequent aggressive behavior is speeding (226 events total, 39.2\% of total aggressive offences), aggressive overtaking (156 events total - overtaking from the right side included, $27 \%$ of total aggressive offences), and the third is breaking safe distance (129 events total, $22.4 \%$ of total aggressive offences). The number of reckless pedestrians is also noteworthy. The frequency of reckless or aggressive driving behavior on the Czech roads is about 6.4 minutes.

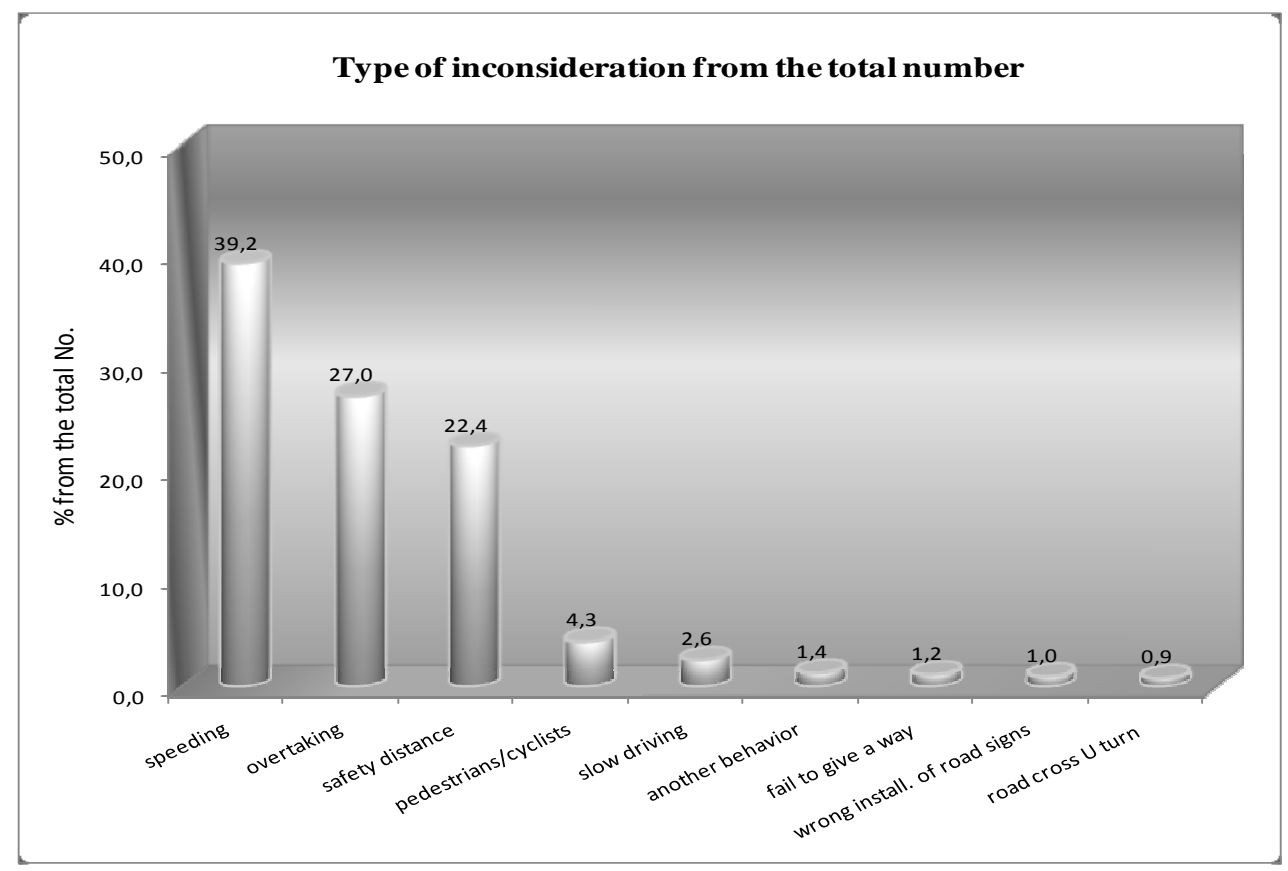

Figure 3: Type of inconsideration from the total number

\section{REFERENCES}

European Commission - Directorate-General for Energy and Transport. 2008. EU energy and transport in figures, Statistical pocketbook 2007, ISBN 978-92-79-07082-2

Ředitelství služby dopravní policie Policejního presidia České republiky, Praha, 2008, Survey on accidents on roads in the Czech Republic, 2007 (Přehled o nehodovosti na pozemních komunikacích v České republice za r. 2007)

Ředitelství služby dopravní policie Policejního presidia České republiky, Praha, 2007, Survey on accidents on roads in the Czech Republic, 2006 (Přehled o nehodovosti na pozemních komunikacích v České republice za r. 2006).

Ředitelství služby dopravní policie Policejního presidia České republiky, Praha, 2006, Survey on accidents on roads in the Czech Republic, 2005 (Přehled o nehodovosti na pozemních komunikacích v České republice za r. 2005).

Novák M., Faber J., Tichý T. Svoboda P. Tatarinov V. Driver psychic state analysis based on EEG signals. Neural Network World, vol. 16, 2006, No.1, 25-39.

Proposal for a Directive of the European parliament and of the Council facilitating crossborder enforcement in the field of road safety, Brussels, 19.3.2008, COM(2008) 151 final, 2008/0062 (COD), pg. 4, http://ec.europa.eu. 